\title{
ANTIBACTERIAL ACTIVITY OF SOME TERRESTRIAL GASTROPODS FROM EGYPT AGAINST STAPHYLOCOCCUS AUREUS AND ESCHERICHIA COLI
}

\author{
Hoda H. Abd-El Azeem ${ }^{1}$; Gamalat Y. Osman ${ }^{1}$; Sabha M. El-Sabbagh²; \\ Sherin K. Sheir ${ }^{1 *}$ \\ ${ }^{\mathbf{1}}$ Zoology Department, Faculty of Sciences, Menoufia University, Menoufia, Egypt \\ ${ }^{2}$ Botany Department, Faculty of Sciences, Menoufia University, Menoufia, Egypt
}

\author{
Article History: \\ Received: 28 May 2020 \\ Revised: 14 June 2020 \\ Accepted: 15 June 2020 \\ Published Online: \\ 1 July 2020 \\ Keywords: \\ Antibacterial activity \\ Electron microscopy \\ Eobania vermiculata \\ Helix aspersa \\ Viscera extract \\ *Correspondence: \\ Sherin Sheir \\ Zoology Department \\ Faculty of Science \\ Menoufia University \\ Menoufia, Egypt \\ E-mail: \\ sherin.sheir@yahoo.com
}

\begin{abstract}
Terrestrial invertebrates are subjected to a wide range of microbial infections throughout their life. Therefore, they have powerful antimicrobial agents. The present study was designed to evaluate the antibacterial efficiency of different extracts of terrestrial gastropods against two pathogenic bacteria: Escherichia coli and Staphylococcus aureus. Phosphate buffer saline (PBS), acetone, and methanol were used to extract viscera, haemolymph, and mucus from the snails, Helix aspersa and Eobania vermiculata, and the slug, Deroceras reticulatum. All extracts from haemolymph and mucus of the three snails did not inhibit the growth of the selected pathogenic bacteria. However, the methanolic extract of E. vermiculata viscera inhibited the growth of $S$. aureus at $50 \%$ concentration; and the inhibition zone reached $12.3 \pm 0.6 \mathrm{~mm}$. In addition, the methanolic extract of $H$. aspersa viscera inhibited the growth of S. aureus at 100 and $50 \%$ concentrations up to $19.3 \pm 0.6$ and $18.0 \pm 0.1 \mathrm{~mm}$, respectively, and induced a moderate decrease in the growth of $E$. coli at $100 \%$ concentration. In addition, scanning electron microscopy (SEM) assured damaging impacts of the methanolic and PBS viscera extracts of the two snails " $H$. aspersa and E. vermiculata" on both E. coli and $S$. aureus. In conclusion, the antibacterial properties of the methanolic viscera extracts of the terrestrial gastropods may encourage the discovery of new and safe antibiotics from animal origin.
\end{abstract}

\section{INTRODUCTION}

Molluscs are widely distributed throughout the world and have many representatives such as slugs, land snails, clams, squids, and octopods ${ }^{[1]}$. The garden snail, Helix aspersa, has several pharmacological activities that are useful in the biomedical area $^{[2]}$. Molluscan bioactive compounds exhibited antitumour, antibacterial, and antiviral properties ${ }^{[3,4]}$. Different snail crude proteins from the freshwater and land snails were previously evaluated for their antimicrobial activity ${ }^{[5]}$. The most active crude proteins were from the land snail, Cryptozona bistrialis, which was capable of completely inhibiting the development of the 
pathogenic bacteria Staphylococcus aureus, Micrococcus luteus, and Pseudomonas aeruginosa, as well as the pathogenic fungi Candida albicans, Aspergillus fumigatus, Penicillium chrysogenum, and Mucor racemosus $^{[5]}$. Some marine molluscs have antimicrobial proteins, which contain a variety of antimicrobial and antioxidant compounds $^{[6]}$. In addition, many of the bioactive compounds such as peptides, sterols, nitrogenous compounds, and fatty acid derivatives were isolated from the molluscan protein-rich meat ${ }^{[6]}$. The antibacterial glycoprotein, achacin (140$160 \mathrm{kDa}$ ), which isolated from the land snail, Achatina fulica, inhibited the growth of Gram-positive bacteria, S. aureus ${ }^{[7]}$. Glycans, peptides, glycopeptides, and proteins were also isolated from the haemolymph of the garden snail, Helix lucorum $^{[8]}$. In addition, the antibacterial substances in the mucus of $H$. aspersa ranged from $30-100 \mathrm{kDa}$, and exhibited activity against $S$. aureus ${ }^{[9]}$.

Many authors explored the bioactive compounds from different parts of the land snails ${ }^{[1,10-13]}$. El Mubarak et al. ${ }^{[10]}$ isolated allantoin and glycolic acid from the mucus of $H$. aspersa, which showed therapeutic properties for human skin. Snail mucus also used in repairing ulcers, and its bioactive compounds-derived drugs can be used in creams to ease scars and skin abrasions ${ }^{[1]}$. The most antimicrobial peptides were found in the haemolymph of the invertebrates, with activity against bacteria, virus, and protozoa ${ }^{[11]}$. Several proline-rich antimicrobial peptides were isolated from the haemolymph of Rapana venosa and Helix lucorum snails that showed strong antibacterial activities against Gram-positive and Gram-negative bacteria $^{[12]}$. The mini-mum inhibition zone was $2 \mathrm{~mm}$ against $S$. aureus in the crude methanolic extract of the gastropod, Babylonia spirata ${ }^{[13]}$. Scanning electron microscopy (SEM) considered as an important tool to directly detect the changes of cell morphology and membrane integrity. Many authors used this technique to describe the antibacterial activity of the plant extracts; for example, Kaya et al. ${ }^{[14]}$ used SEM to detect shrinking and degradation of the cell walls of Staphylococcus aureus and Escherichia coli treated with chloroform, acetone, and methanolic extracts of Ocimum basilicum. Ramli et $a .^{[15]}$ also reported rupture of the cell wall and leakage of the cytoplasm from treated bacteria with ethanolic extract of Syzygium polyanthum L. (Salam) leaves. In addition, the treatment of $S$. aures by the ethyl acetate extract of the fungus, Nigrospora sphaerica, caused shrinkage of the cell surface, irregular shape, and cleavage of the cell envelope ${ }^{[16]}$. Therefore, the present study aimed to evaluate the potential antibacterial properties of different tissue extracts of different gastropods against bacterial strains, $S$. aureus and $E$. coli, using the agar well diffusion method and SEM.

\section{MATERIAL AND METHODS Animals}

The terrestrial gastropod snails used in the present study were $H$. aspersa, Eiobania vermiculata, and the slug, Deroceras reticulatum. They were collected from the infested ornamental and grass plants. The gastropods were maintained under laboratory conditions at room temperature and $80 \%$ relative humidity.

\section{Animals' maintenance}

Wild individuals (10-15, average weight $4.0 \pm 0.5 \mathrm{~g} /$ snail and $2.0 \pm 0.7 \mathrm{~g} / \mathrm{slug}$ ) were placed in glass containers measuring $(15 \mathrm{~cm}$ width $\times 15 \mathrm{~cm}$ height $\times 22 \mathrm{~cm}$ length). The containers were filled with sandy loam. The lid of the containers was a muselin material for ventilation. The gastropods were daily supplied with fresh lettuce (Lactuca sativa) leaves and water for soil humidity. The remaining food and faecal matter were removed at the end of every other day. The gastropods were acclimatised under laboratory conditions for at least four weeks before being used in the screening tests. 


\section{Haemolymph, mucus, and tissue extraction}

Haemolymph samples were collected from snails and slug from the cephalic sinus using a syringe needle (21 gauge). Mucus production was stimulated by gently holding the snails and slugs. It was collected by plastic Pasteur pipette and pooled into one aliquot. The mucus was left to settle and diluted with solvents. The soft bodies of gastropods were rinsed with distilled water and let to dry, then removed from the shells and dissected. The internal viscera were cut into small pieces and homogenised with different solvents such as phosphate buffer saline (PBS), acetone, and methanol, then were kept on ice ${ }^{[13,9]}$. Homogenates were centrifuged at maximum speed in the cooling centrifuge, and the supernatants were kept on ice till the inculcation of samples.

\section{Extraction of bioactive compounds}

The extraction was classified into three trials using three solvents. In the $1^{\text {st }}$ trial, the viscera tissue extract was carried out by PBS, and was used at concentrations $100 \%, 50 \%$, and $25 \%$. The PBS mucus extract (highly viscous) was used at concentrations $50 \%, 25 \%$, and $12.5 \%$, while the PBS haemolymph extract was used at concentrations $100 \%$ and $50 \%$. In the $2^{\text {nd }}$ trial, the viscera tissue extract was done by acetone, and was used at concentrations $100 \%$ and $50 \%$, while the acetone mucus extract was used at concentration $50 \%$ only. In the $3^{\text {rd }}$ trial, the viscera tissue was extracted by methanol, and was used at concentrations $100 \%$ and $50 \%$, while the methanolic mucus extract was used at concentration $50 \%$ only.

\section{Antibacterial assay}

Gastropod crude extracts of haemolymph, mucus, and viscera were tested for inhibition of growth of the bacterial strains, S. aureus (ATCC6598, American Type Culture Collection, Manassas, VA, USA) and E. coli (ATCC8739). Bacterial strains from stock cultures were kept in the refrigerator, and inoculated into sterilized
Muller Hinton agar plates. The antibacterial activity was determined by the agar well diffusion method ${ }^{[17]}$. The nutrient agar plates were swabbed with the respective 24 hours broth culture of the used bacteria species, and kept for 15 minutes in a laminar chamber. Wells $(5 \mathrm{~mm})$ were cut in the agar media for the inculcation of $100 \mu \mathrm{L}$ gastropod extracts. The controls were used with/without solvents to assess their effect on bacteria. The plates were incubated at $37^{\circ} \mathrm{C}$ for 24 hours. A standard antibiotic (amoxicillin, $1000 \mu \mathrm{g} / \mathrm{mL}$ ) was used to confirm the antibacterial activity of the extracts. The diameters of inhibition zones were the area devoid of bacterial growth around the wells, and were measured as a distance $(\mathrm{mm})$ and a percentage $(\%)$ of the total diameter of the bacterial growth on growth media (Figure 1) as the following: Inhibition of growth $(\%)=($ total diameter of the Petri dish $(\mathrm{mm}) /$ diameter of the inhibition zone $(\mathrm{mm})$ against the tested organism)

\section{Scanning electron microscopy (SEM)}

The antibacterial activity of the PBS and methanol extracts of $H$. aspersa and $E$. vermiculata viscera against both $S$. aureus and $E$. coli was further observed by using the SEM examination. The bacterial inoculums $(100 \mu \mathrm{L})$ was inoculated into a flask containing $18.9 \mathrm{~mL}$ of Mueller Hinton broth and incubated on a shaker, $150 \mathrm{rpm}$ for 18 hours at $37^{\circ} \mathrm{C}$. After incubation period, $1 \mathrm{~mL}$ of each extract was added to the bacterial culture. At the same time, the bacterial culture was added to another flask without extract as a control. Then, the flasks were incubated at $37^{\circ} \mathrm{C}$ at $150 \mathrm{rpm}$ for 12 hours. After the incubation time, the pellets of the treated bacterial culture were fixed in $2.5 \%$ glutaraldehyde $(\mathrm{v} / \mathrm{v})$ buffered with 0.1 mol sodium phosphate buffer $(\mathrm{pH}=7.2)$. For the postfixation step, samples were suspended in $1 \%$ osmium tetroxide in $0.1 \mathrm{~mol}$ phosphate buffer ( $\mathrm{pH}=7.2$ ) for one hour, then centrifuged, and the supernatant was discarded. Thereafter, the pellet was dehydrated using ethanol series for 10 minutes. 


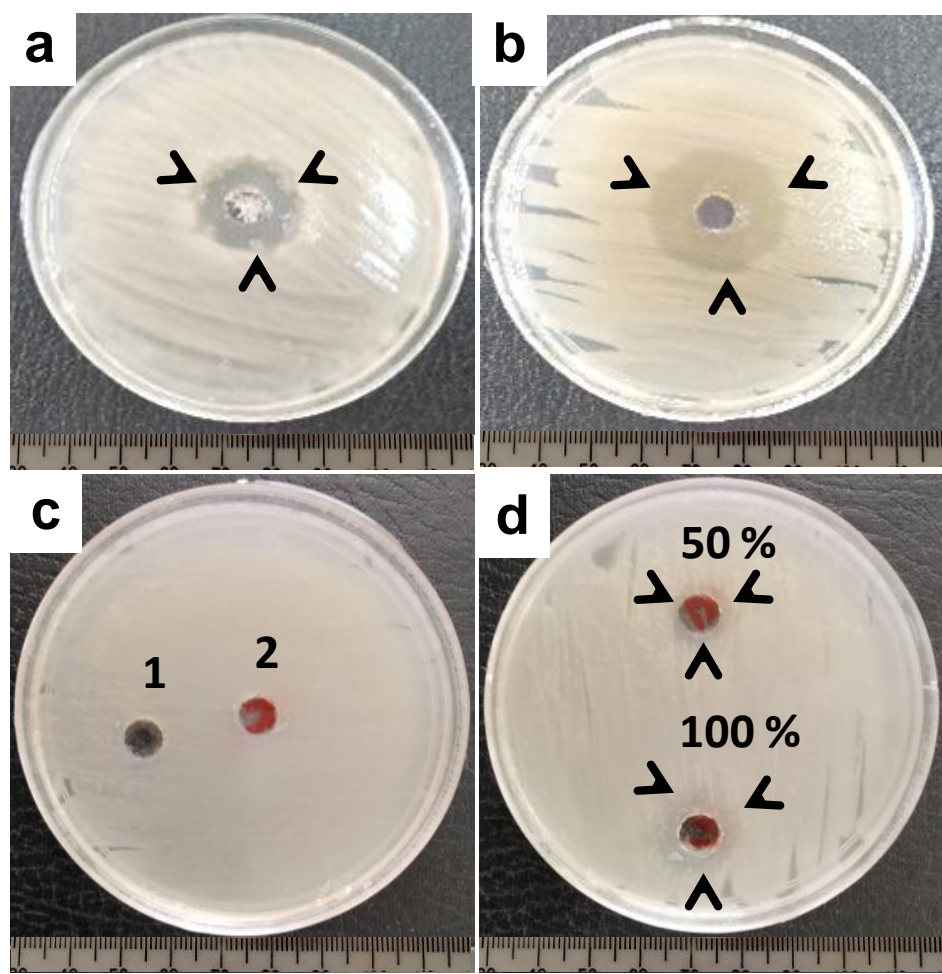

Figure 1: Antibacterial activity of the methanolic and phosphate buffer saline (PBS) viscera extracts of the terrestrial gastropods against $S$. aureus and E. coli. (a) amoxicillin $(1000 \mu \mathrm{g} / \mathrm{mL})$ antibiotic against S. aureus; (b) amoxicillin antibiotic against E. coli; (c) $S$. aureus growth in the absence (1) or presence of the methanol (2); (d) S. aureus growth in the presence of $50 \%$ or $100 \%$ methanolic $H$. aspersa viscera extract; (e) $S$. aureus growth in the presence of $50 \%$ methanolic E. vermiculata viscera extract; (f) $E$. coli growth in presence of $100 \%$ methanolic $H$. aspersa viscera extract, or methanol (M); (g) S. aureus growth in the presence of PBS; (h) S. aureus growth in the presence of $100 \%$ PBS $H$. aspersa viscera extract. Arrow heads showing the inhibition zone.

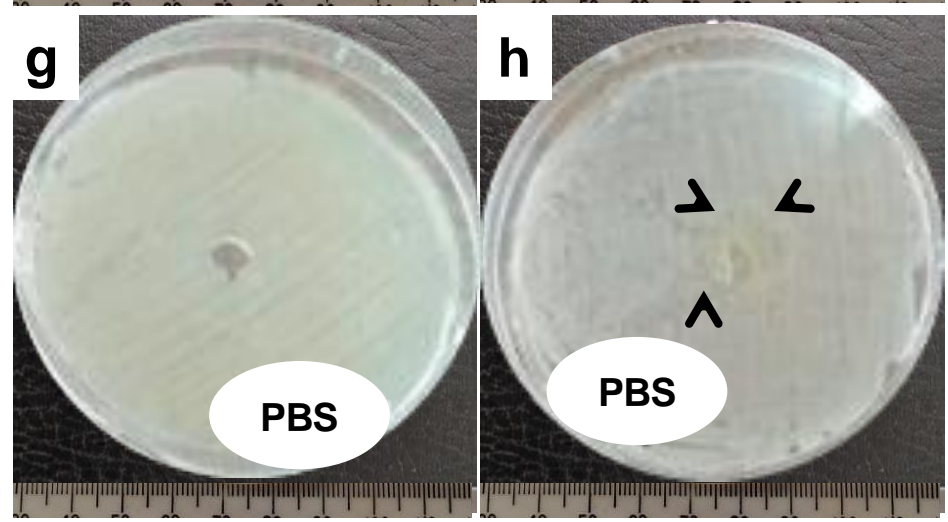

Alexandria, Egypt. All chemicals used in the present study were pure and purchased from Sigma-Aldrich Corp (St. Louis, MO USA).

mounted onto stubs using double-sided carbon tape, and then were gold coated. Samples were examined and photographed at the desired magnifications using JSMIT200 SEM series (JEOL Ltd., Tokyo, Japan), at Electron Microscope Unit, Faculty of Science, Alexandria University,

\section{Statistical analysis}

All the tests were run in triplicates or more. Data were expressed as mean \pm standard deviation and analysed using Statgraphics 
Centurion XVI (Stat-Point Technologies Inc., Warrenton, VA, USA). Statistical analysis was carried out using One-way ANOVA with Fisher's Least Significant Difference (LSD) post-hoc test to set the significant difference $(P \leq 0.05)$ between the inhibition zones of the different groups.

\section{RESULTS}

The antibacterial activity of the terrestrial gastropod extracts that was detected by using the agar well diffusion method

Amoxicillin antibiotic caused inhibition in the growth of $S$. aureus and $E$. coli by $24 \pm 1.0$ and $16.3 \pm 0.6 \mathrm{~mm}$, respectively (Figures $1 \mathrm{a}$ and $\mathrm{b}$ ). In the $1^{\text {st }}$ trial, PBS extracts of terrestrial gastropods' mucus and haemolymph did not show any antibacterial activity against any of the used bacterial strains at any concentration. However, PBS extract of $H$. aspersa viscera at concentration $100 \%$ inhibited the growth of $S$. aureus with a significant inhibition ratio $=17 \% \quad(P \leq 0.0001$, Figure $1 \mathrm{~h}$ and Table 1$)$. In the $2^{\text {nd }}$ trail, the acetone extracts of terrestrial gastropods' mucus, haemolymph, and viscera did not show any antibacterial activity toward any of the used bacterial strains.

In the $3^{\text {rd }}$ trail, the methanolic extracts of terrestrial gastropods' mucus and haemolymph did not show any antibacterial activity at any of the investigated concentrations against the used bacterial strains. Meanwhile, the methanolic extracts (50 and $100 \%$ ) of $H$. aspersa viscera showed a significant $(P \leq 0.05)$ antibacterial activity (inhibition zone $=25.7-27.6 \%$ ) against $S$. aureus when compared with the control group (Figure 1d and Table 1). In addition, the antibacterial activity of the $50 \%$ methanolic extract of $H$. aspersa viscera was significantly higher $(P \leq 0.05$, ANOVA) than that of Eobania vermiculata viscera methanolic extract at the same concentration (Table 1). All the tested extracts of the terrestrial gastropods did not show any antibacterial activity against E. coli in the current study, except the $100 \%$ methanolic $H$. aspersa viscera extract, which showed a medium effect on the growth of E. coli (Figure 1f).

Table 1: Antibacterial activity of viscera from different terrestrial gastropods extracted with phosphate buffer saline (PBS) or methanol.

\begin{tabular}{lcccc}
\hline \multirow{2}{*}{ Solvents } & Gastropods & $\begin{array}{c}\text { Bacterial } \\
\text { Species }\end{array}$ & \multicolumn{2}{c}{ Zone of inhibition, mm and (\%) } \\
\cline { 3 - 4 } PBS & Helix & Staphylococcus & $12.0 \pm 0.6^{*}(17.0)$ & Viscera \\
\cline { 3 - 4 } Methanol & aspersa & Aureus & & $-\mathrm{ve}$ \\
& Helix & & $19.3 \pm 0.6^{*}(27.6)$ & $18.0 \pm 0.1^{* \dagger}(25.7)$ \\
& aspersa & Staphylococcus & & $12.3 \pm 0.6^{*}(17.6)$ \\
& Eobania & aureus & -ve & \\
\hline
\end{tabular}

Data were expressed as mean \pm standard deviation $(n \geq 3)$. -ve: no antibacterial activity, $* P \leq 0.05$ : compared to the control group, ${ }^{\dagger} P \leq 0.05$ : compared with the $50 \%$ methanolic extract of Eobania vermiculata viscera.

The antibacterial activity of the terrestrial gastropod extracts that was detected by using SEM examination

The control E. coli appeared as typical rod shape with maintained rigidity and smooth surface (Figure 2a). E. coli exposed to PBS or methanol alone showed normal appearance as the control one (Figures 2a-c). The main abnormalities of the E. coli exposed to the PBS viscera extract of 

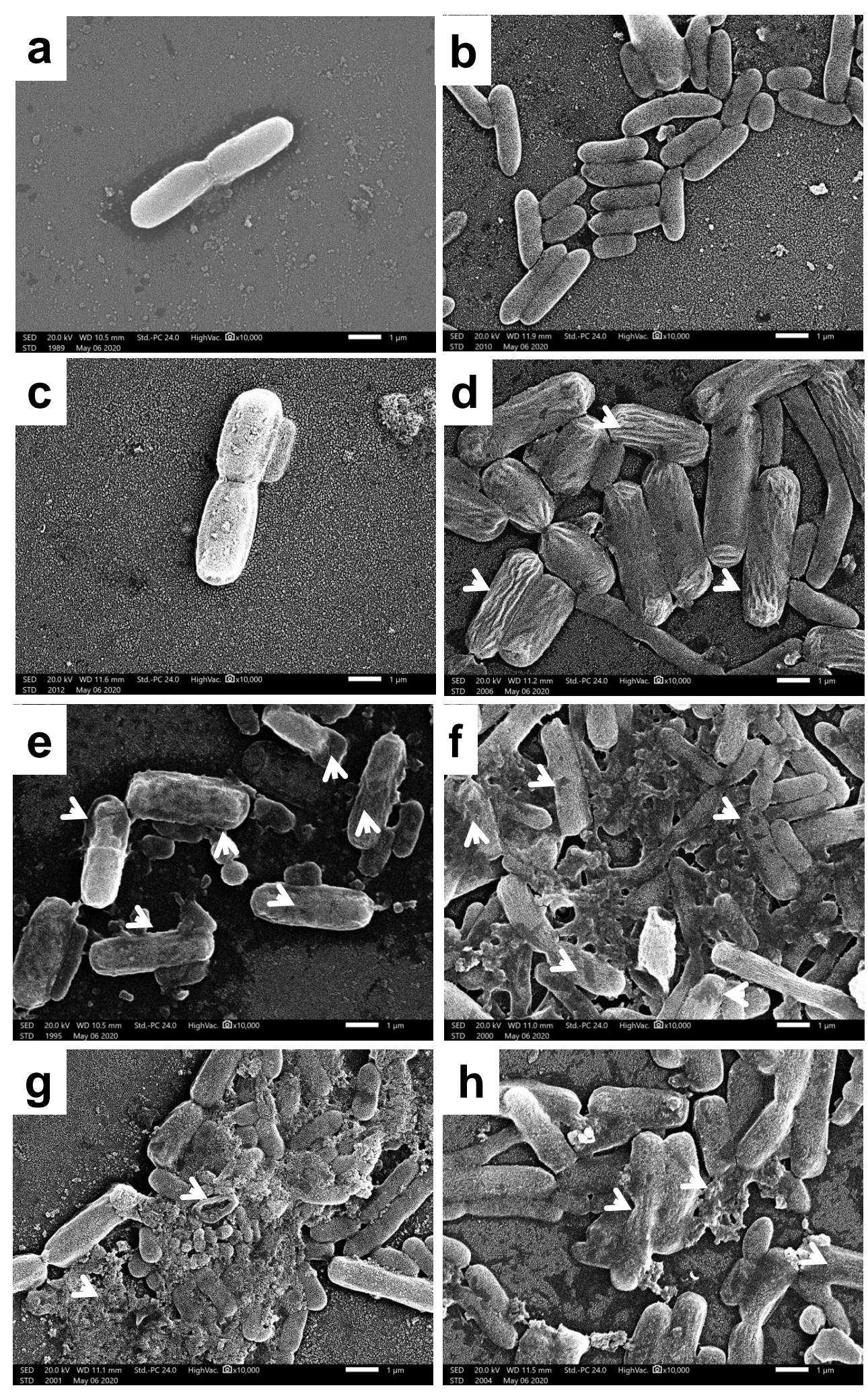

Figure 2: Scanning electron micrographs showing the antibacterial activity of the methanolic and phosphate buffer saline (PBS) viscera extracts of the terrestrial gastropods against E. coli. (a) control E. coli; (b) E. coli + PBS; (c) E. coli + methanol; (d) E. coli $+100 \%$ PBS $H$. aspersa viscera extract; (e) E. coli $+50 \%$ methanolic $H$. aspersa viscera extract; (f) $E$. coli $+100 \%$ methanolic $H$. aspersa viscera extract; $(\mathbf{g}, \mathbf{h})$ E. coli $+50 \%$ methanolic E. vermiculata viscera extract. Arrow heads showing abnormalities such as curliness, swollen cells, cavities, cell debris, lyses, and cuts. 
H. aspersa were wrinkles and curliness of the surface and swollen (Figure 2d). However, exposure of the E. coli to the methanolic extracts of $H$. aspersa and $E$. vermiculata viscera at different concentrations induced several morphological alterations. Such alterations were represented in formations of cavities and cell debris between and on the bacterial cells, the cell envelope was eroded and cut abruptly, some cells were lysed, and the surface was completely rough (Figures $2 \mathrm{e}-\mathrm{h})$.

The control S. aureus appeared as the typical coccoid shape cells, rigid, with smooth round surface (Figure 3a). S. aureus exposed to PBS or methanol alone appeared as the control one with normal outer shape (Figures $3 b$ and $c$ ). The main abnormalities of $S$. aureus exposed to the PBS viscera extract of $H$. aspersa were the increase in dead cells and debris, as well as changes in the shape, e.g. swelling or flatness (Figure 3d). However, exposure of $S$. aureus to the methanolic extracts of $H$. aspersa viscera at different concentrations induced several morphological alterations, which were represented in cell death, lyses, increased cell debris between and on the bacterial cells, and the rough bacterial surface (Figures 3e-g). In addition, the 50\% methanolic extract of E. vermiculata viscera caused formations of cavities or pits on the outer wall of $S$. aureus, cell lyses, and change in the cells shape (Figure 3h).

\section{DISCUSSION}

In the current work, methanol was the most powerful solvent for extracting the bioactive compounds from the tested gastropods. In addition, the terrestrial snail, $H$. aspersa, viscera methanolic extract recorded the highest antibacterial activity against $S$. aureus at different concentrations, and some of its antibacterial effects were also detected against Escherichia coli and were confirmed by SEM examination. The potent inhibitory activity of the snails extract against bacterial growth may due to the presence of proline-rich peptides ${ }^{[18]}$. Also, some toxic compounds could be present in the extract of internal tissues (hypobranchial body) of the marine gastropod, Murex trunculus, named as murexine (choline derivative ${ }^{[19]}$ ). In addition, the role of digestive enzymes of the marine snail, Cypraea errones against ascidian (Tunicata) antimicrobial molecules was discussed ${ }^{[20]}$. In addition, the maximum antibacterial activity in the gut tissue of the bivalve, gastropod and crustacean samples were recorded due to the presence of highest content of proteins rather than other body parts $^{[21]}$. Also, marine invertebrates have bioactive nitrogenous compounds which contain sodium nitrates as an antibacterial chemical (tetrodotoxin, is a potent neurotoxin found in several taxa of terrestrial invertebrates such as the terrestrial flatworms $^{[22]}$. Ulagesan and $\mathrm{Kim}^{[5]}$ reported potent antibacterial activity in one of the seven studied snails (terrestrial) and attributed this to the different proteins with antimicrobial properties among snails. The antibacterial activity of some snails could be transferred from their diet as biologically active compounds ${ }^{[23]}$. Poaceae is the natural diet of $H$. aspersa, which has an antimicrobial activity to protect the crop $^{[24]}$.

In the current results, methanolic tissue extracts inhibited the growth of $S$. aureus. Antibacterial activity of the methanolic extract of the whole body marine gastropod "Hemifusus pugilinus" against E. coli, but not $S$. aureus, was detected by Anand et $a l .{ }^{[25]}$. In addition, methanolic extract of molluscs and crustaceans exhibited higher antibacterial activity than water extract ${ }^{[21]}$. The lipophilic extracts with methanol or chloroform of Aplysia eggs showed significant bactericidal effect than water ${ }^{[23]}$. The highest antibacterial activity of the marine snail, Babylonia spirata was extracted by methanolic and ethanolic solvents ${ }^{[13]}$.

In the current work, the agar well diffusion method indicated that tissue extracts of snails viscera inhibited mainly the growth of $S$. aureus, but inhibited the E. coli growth with a lesser extent. 

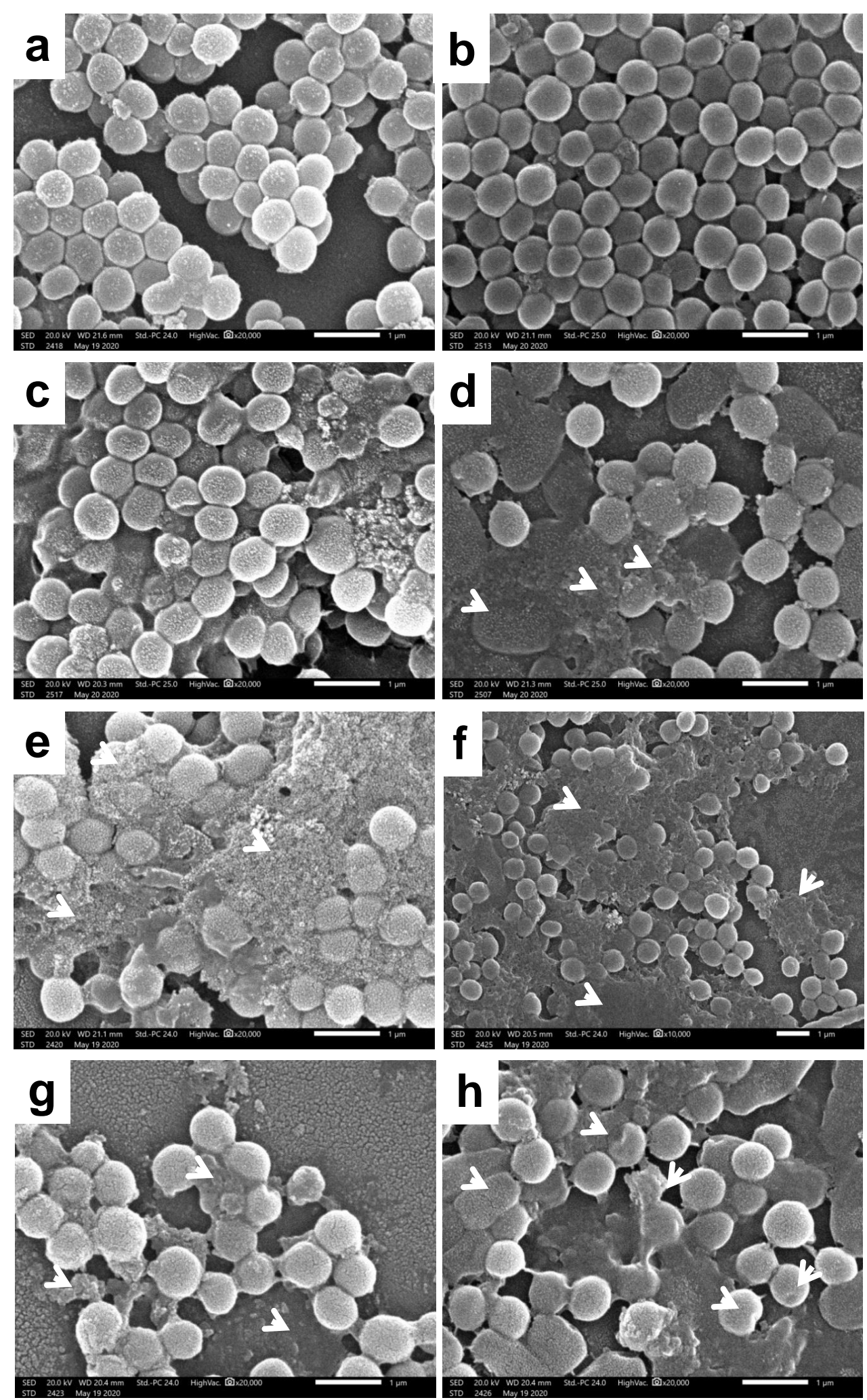

Figure 3: Scanning electron micrographs showing the antibacterial activity of the methanolic and phosphate buffer saline (PBS) viscera extracts of the terrestrial gastropods against S. aureus. (a) control S. aureus; (b) S. aureus + PBS; (c) S. aureus + methanol; (d) S. aureus $+100 \%$ PBS H. aspersa viscera extract; (e) S. aureus $+50 \%$ methanolic H. aspersa viscera extract; (f, g) S. aureus $+100 \%$ methanolic H. aspersa viscera extract; (h) S. aureus $+50 \%$ methanolic E. vermiculata viscera extract. Arrow heads showing abnormalities such as cell debris, lyses, pits on the cell wall, and change in cell shape. 
Benkendorff et al. ${ }^{[23]}$ found that $S$. aureus as Gram-positive bacteria was more susceptible to inhibition of growth by gastropod extracts than other bacteria species. Also, no antibacterial activity of Mytilus galloprovincialis haemolymph against $E$. coli was detected ${ }^{[26]}$. This could be explained by that the resistance of E. coli (Gram-negative) bacteria was due to their complex wall structure (proteinlipopolysaccharides), which can exclude most of the active compounds ${ }^{[27]}$. Ramli et $a l .{ }^{[15]}$ and Othman at al. ${ }^{[28]}$ discussed the disadvantages of the agar well diffusion methods, as the difficulty of diffusing the hydrophobic compounds (most of the bioactive compounds) through the agar. In addition, Ramli et $a .^{[15]}$ recorded more antibacterial effect of the methanolic extract of Syzygium polyanthum L. (Salam) leaves against the gram-positive bacteria than the gram-negative bacteria species, as in the present study. However, SEM method approved severe deformities in $E$. coli treated with snails viscera extracts (PBS and methanol). Ibrahim et al. ${ }^{[16]}$ recorded similar effects of the ethyl acetate extract of endophytic fungus, Nigrospora sphaerica, against the gramnegative bacteria, Klebsiella pneumonia. They explained the happened antibacterial effects as follows: (a) the extracts caused damage to the cell envelope (due to their action on the peptidoglycan layer) and consequently loss of cellular contents from cytoplasm of cells, (b) this also could cause influx/efflux of water in/out of the cells (swollen/shrinkage) due to osmotic unbalances. In addition, the active ingredients of the bactericidal material could interfere with the lipid bilayer of the bacterial cell membrane and accumulate between the fatty acids' chains ${ }^{[29]}$.

In the present investigation, haemolymph and mucus extracts of snails did not inhibit the growth of $S$. aureus or E. coli. Antibacterial activity of haemolymph and mucus could be modified or degraded during the process of extraction ${ }^{[20]}$ or due to the presence of other micro- organisms (symbiots/pathogens) which already stimulate the mucus production and/or immune activity as these are the first and second lines of defence ${ }^{[23]}$. No activity of Achatina fulica mucus against Pseudomonas Aeruginosa bacteria was recorded $^{[30,9]}$. The $H$. aspersa mucus had a weak antibacterial ability, which may be due its protein content and/or the extraction techniques ${ }^{[9]}$.

In conclusion, the present study confirmed that $H$. aspersa, and to a lesser extent E. vermiculata, viscera extracts have bactericidal properties by using the agar well diffusion method and SEM technique. The present study can open a novel avenue in the antibiotics research. Therefore, further studies are required to identify and purify the bioactive compounds of gastropod extracts for manufacturing new antibiotics.

\section{ACKNOWLEDGMENTS}

Authors are grateful to Aia Salman and Briksam Salah (Botany and Microbiology Department, Faculty of Science, Menoufia University) for providing help regarding the microbial experiments.

\section{FUNDING SOURCE DISCLOSURE}

This study received no specific grant from any funding agency in public, commercial, or not-for-profit sectors.

\section{CONFLICT OF INTEREST}

The authors declare no conflict of interest.

\section{AUTHORS' CONTRIBUTIONS}

HHA and KSK carried out the experiments, summarised the results, and wrote the manuscript. GYO suggested the research idea and revised the manuscript. SME provided the materials and lab for the microbiology experiments. SKS performed the statistical analysis.

\section{REFERENCES}

[1] Dang, V. T.; Benkendorff, K.; Green, T. et al. (2015). Marine snails and slugs: a great place to look for antiviral drugs. J Virol, 89(16): 8114-8118. 
[2] Gabriel, U. I.; Mirela, S. and Ionel, J. (2011). Quantification of mucoproteins (glycoproteins) from snails mucus, Helix aspersa and Helix pomatia. J Agroaliment Proc Technol, 17(4): 410-413.

[3] Kamiya, H.; Muramoto, K. and Ogata, K. (1984). Antibacterial activity in the egg mass of a sea hare. Experientia, 40: 947-949.

[4] Rajaganapathy, J.; Thyagarajan, S. P. and Edward, J. K. (2000). Study on cephalopod's ink for anti-retroviral activity. Indian J Exp Biol, 38: 519520.

[5] Ulagesan, S. and Kim, H. J. (2018). Antibacterial and antifungal activities of proteins extracted from seven different snails. Appl Sci, 8(8): 1362 (DOI: 10.3390/app8081362).

[6] Blunt, J. W.; Copp, B. R.; Hu, W. P. et al. (2009). Marine natural products. Nat Prod Rep, 26(2): 170-244.

[7] Otsuka-Fuchino, H.; Watanabe, Y. and Hirakawa, C. (1992). Bactericidal action of a glycoprotein from the body surface mucus of giant African snail. Comp Biochem Physiol C, 101: 607613.

[8] De Smet, L.; Dimitrov, I.; Debyser, G. et al. (2011). The cDNA sequence of three hemocyanin subunits from the garden snail Helix lucorum. Gene, 487(2): 118-128.

[9] Pitt, S. J.; Graham, M. A.; Dedi, C. G. et al. (2015). Antimicrobial properties of mucus from the brown garden snail Helix aspersa. Br J Biomed Sci, 72(4): 174-181.

[10] El Mubarak, M. A. S.; Lamari, F. N. and Kontoyannis, C. (2013). Simultaneous determination of allantoin and glycolic acid in snail mucus and cosmetic creams with high performance liquid chromatography and ultraviolet detection. J Chromatogr A, 1322: 49-53.

[11] Li, H.; Parisi, M.-G. and Parrinello, N. (2011). Molluscan antimicrobial peptides, a review from activity-based evidences to computer-assisted sequences. Invertebrate Survival Journal, 8: 85-97.

[12] Dolashka, P.; Moshtanska, V.; Borisova, V. et al. (2011). Antimicrobial proline-rich peptides from the hemolymph of marine snail Rapana venosa. Peptides, 32(7): 14771483.

[13] Periyasamy, N.; Srinivasan, M. and Balakrishnan, S. (2012). Antimicrobial activities of the tissue extracts of Babylonia spirata Linnaeus, 1758 (Mollusca: Gastropoda) from Thazhanguda, southeast coast of India. Asian Pac J Trop Biomed, 2: 36-40.

[14] Kaya, I.; Yigit, N. and Benli, M. (2008). Antimicrobial activity of various extracts of ocimum basilicum L. and observation of the inhibition effect on bacterial cells by use of scanning electron microscopy. Afr J Tradit Complement Altern Med, 5(4): 363-369.

[15] Ramli, S.; Radu, S.; Shaari, K. et al. (2017). Antibacterial activity of ethanolic extract of Syzygium polyanthum L. (Salam) leaves against foodborne pathogens and application as food sanitizer. Biomed Res Int, 2017: 9024246 (DOI: 10.1155/2017/ 9024246).

[16] Ibrahim, D.; Lee, C. C.; Yenn, T. W. et al. (2015). Effect of the extract of endophytic fungus, Nigrospora sphaerica CL-OP 30, against the growth of Methicillin resistant Staphylococcus aureus (MRSA) and Klebsiella pneumonia cells. Trop J Pharm Res, 14(11): 2091-2097.

[17] Bauer, A. W.; Kirby, W. M.; Sherris, J. C. et al. (1966). Antibiotic susceptibility testing by a standardized single disk method. Am J Clin Pathol, 45(4): 493-496.

[18] Dolashka, P.; Dolashki, A.; Voelter, W. et al. (2015). Antimicrobial activity of peptides from the hemolymph of Helix lucorum snails. Int J Curr Microbiol Appl Sci, 4(4): 1061-1071. 
[19] Erspamer, V. and Benati, O. (1953). Identification of murexine as $\beta$-[imidazolyl-(4)]-acryl-choline. Science, 117(3033): 161-162.

[20] Anand, T. P. and Edward, J. K. P. (2002). Antimicrobial activity in the tissue extracts of five species of cowries cypraea spp. (Mollusca: Gastropoda) and an ascidian Didemnum psammathodes (Tunicata: Didemnidae). Indian J Mar Sci, 31(3): 239-242.

[21] Kiran, N.; Siddiqui, G.; Khan, A. N. et al. (2014). Extraction and screening of bioactive compounds with antimicrobial properties from selected species of mollusk and crustacean. J Clin Cell Immunol, 5(1): 1000189 (DOI.org/10.4172/21559899.1000189).

[22] Stokes, A. N.; Ducey, P. K.; Neuman-Lee, L. et al. (2014). Confirmation and distribution of tetrodotoxin for the first time in terrestrial invertebrates: two terrestrial flatworm species (Bipalium adventitium and Bipalium kewense). PLOS One, 9(6): e100718 (DOI: 10.1371/journal.pone.0100718).

[23] Benkendorff, K.; Davis, A. R. and Bremner, J. B. (2001). Chemical defense in the egg masses of benthic invertebrates: an assessment of antibacterial activity in 39 mollusks and 4 polychaetes. J Invertbr Pathol, 78(2): 109-118.

[24] Chevalie, L.; Desbuquois, C.; Le Lannic, J. et al. (2001). Poaceae in the natural diet of the snail Helix aspersa Müller (Gastropoda, Pulmonata). C R Acad Sci III, 324(11): 979-987.

[25] Anand, T. P.; Rajaganapathy, J. and Edward, J. K. P. (1997). Antibacterial activity of marine molluscs from Portonovo region. Indian J Mar Sci, 26(2): 206-208.

[26] Hubert, F.; van der Knaap, W.; Noël, T. et al. (1996). Cytotoxic and antibacterial properties of Mytilus galloprovincialis, Ostrea edulis and Crassostrea gigas (bivalve molluscs) hemolymph. Aquat Living Resour, 9(2): 115-124.

[27] Im, W. and Khalid, S. (2020). Molecular simulations of Gramnegative bacterial membranes come of age. Annu Rev Phys Chem. 71: 181-188.

[28] Othman, M.; Loh, H. S.; Wiart, C. et al. (2011). Optimal methods for evaluating antimicrobial activities from plant extracts. J Microbiol Methods, 84(2): 161-166.

[29] Dorman, H. J. and Deans, S. G. (2000). Antimicrobial agents from plants: antibacterial activity of plant volatile oils. J Appl Microbiol, 88(2): 308-316.

[30] Santana, W. A.; de Melo, C. M. and Cardoso, J. C. (2012). Assessment of antimicrobial activity and healing potential of mucous secretion of Achatina fulica. Int J Morphol, 30(2): 365-373.

\section{How to cite this article:}

Abd-El Azeem, H. H.; Osman, G. Y.; El-Sabbagh, S. M. and Sheir, S. K. (2020). Antibacterial activity of some terrestrial gastropods from Egypt against Staphylococcus aureus and Escherichia coli. Egyptian Journal of Zoology, 74: 1-12 (DOI: 10.12816/ejz.2020.26009.1024). 


\title{
النشاط المضاد للبكتريا لبعض البطنقدميات الأرضية من مصر ضد بكتريا \\ "ESCHERICHIA COLI و STAPHYLOCOCCUS AUREUS"
}

\author{
هلاي حسن عبد العظيم¹، جمالات يوسف عثمان 1، صابحة محمود الصباغ² ، شيرين خليفة شعير1

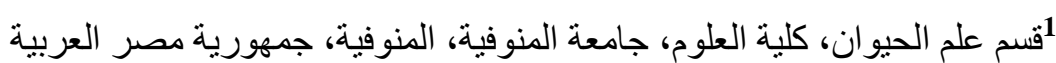 \\ 2قنم النبات و الميكروبيولوجي، كلية العلوم، جامعة المنوفية المنية، المنوفية، جمهورية مصرية العربة العربية
}

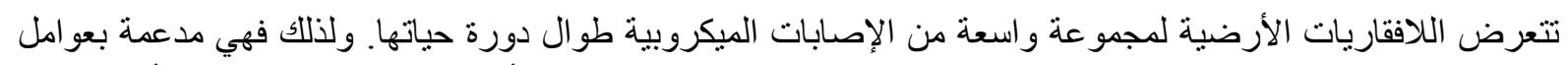

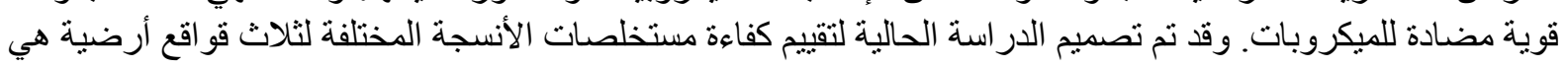

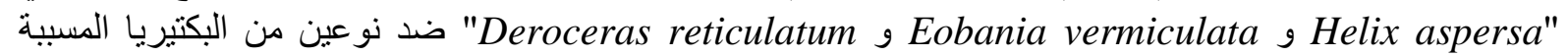
للأمر اض البشرية هما "Staphylococcus aureus و Escherichia coli". وقد تم استخلاص كل من الأحشاء،

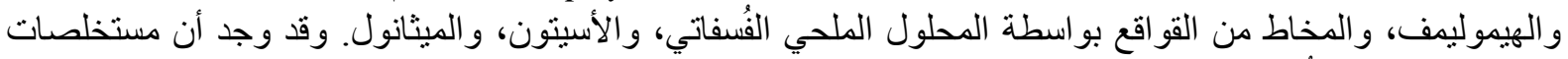

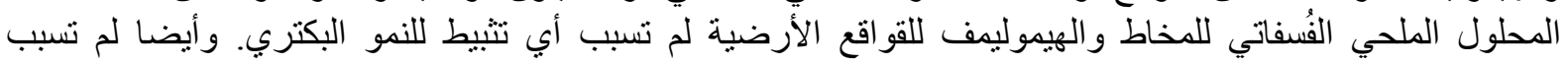

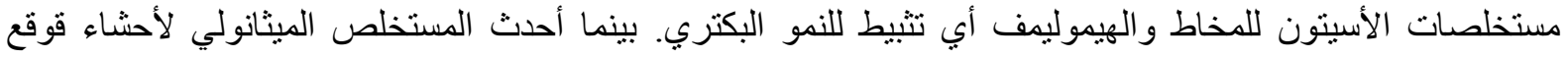

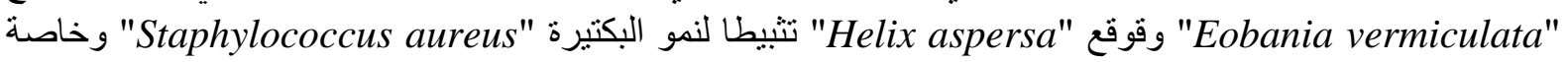

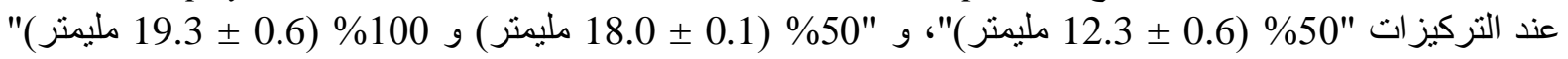

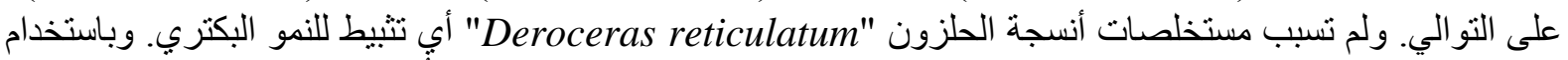

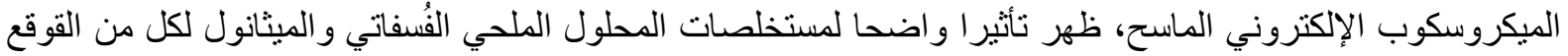

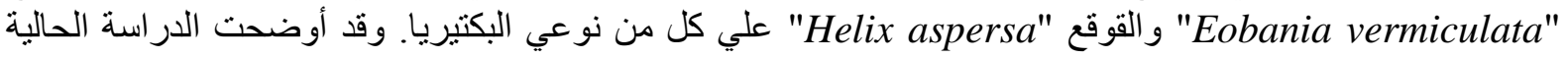

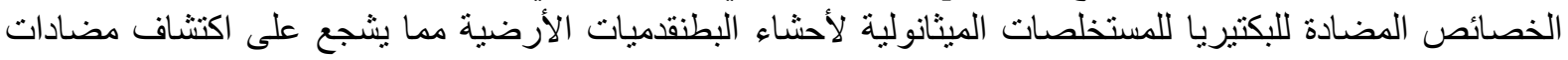
حيوية جديدة وآمنة من أصل حيو انيكي. للمبني 